\title{
$\mathrm{PEO}$ 를 이용한 Alg-Na 바인더의 물성향상
}

\author{
박용완 ${ }^{\dagger} \cdot$ 김의화 $^{1} \cdot$ 조호현 $^{2}$ \\ 한국니트산업연구원, ${ }^{1}$ 신한대학교 섬유소재공학과, ${ }^{2}$ 서정대학교 섬유패션디자인과
}

\section{Improvement of Binding Property of the Alg-Na/PEO Blends}

\author{
Yong Wan Park ${ }^{\dagger}$, Eui Hwa Kim ${ }^{1}$ and Ho Hyun $\mathrm{Cho}^{2}$ \\ Korea Institute for Knit Industry, Iksan, Korea \\ ${ }^{1}$ Department of Textile Materials Engineering, Shinhan University, Dongducheon, Korea \\ ${ }^{2}$ Department of Textile and Fashion Design, Seojeong College, Pocheon, Korea
}

(Received: January 6, 2014 / Revised: January 28, 2014 / Accepted: February 28, 2014)

\begin{abstract}
There has been increasing demand to the eco-friendly materials such as phytoncide which is extracted to plants in the textile industry, recently. It is interesting that alginic acid sodium salt(Alg-Na) is used to eco-friendly binder for the functional capsule finishing. In this study, we made PEO/Alg-Na blend solutions of various ratio and observed the changing binding property of the blend solutions according to PEO contents through FT-IR, DSC, contact angle, peel strength, etc. The viscosity of Alg-Na/PEO blend solutions increased with increase of contents and the viscosity quickly increased with increase of PEO content in Alg-Na 5\% content, specially. It is shown that the hydrogen bond peak by blend of Alg-Na and PEO found through FT-IR analysis but the peak decreased in PEO above $60 \%$ content. And the peel strength was predominant in PEO 50\% ratio.
\end{abstract}

Keywords: alginic acid sodium salt(Alg-Na), polyethylene oxide(PEO), binder, adhesive strength, capsule finishing

\section{1. 서 론}

최근 들어 새집증후군 등 환경오염에 따른 알러지 성 질환이나 아토피 피부질환 환자가 증가함에 따라 인체 친화적인 천연 소재가 관심을 끌고 있다. 의류 에서도 마찬가지로 합성소재보다 자연 친화적이고 인체 친화적인 기능성 소재에 대한 수요가 증가하고 있으며 오가닉 코튼, 키토산 섬유, 기능성 미네랄 함 유섬유 및 옥수수로부터 얻어진 PLA 섬유 등이 시 판되고 있고 이들은 항균·소취성 등 여러 가지 기능 성을 갖는 것으로 알려져 있다.

또한 가공제중에서도 식물에서 추출되는 피톤치드 와 같은 천연 추출물들은 미생물의 번식과 생장을 억제하여 항균성 및 소취성을 가질 뿐만 아니라 스 트레스 완화, 면역기능 향상 등 다양한 기능을 가지 고 있고 일반적인 합성 가공제에서 나타나는 포름알 데하이드와 같은 잠재적 유해요인이 적어 합성가공

${ }^{\dagger}$ Corresponding author: Yong Wan Park (pywspiri@@knitcenter.re.kr) Tel.: +82-63-830-3551 Fax.: +82-63-830-3540 (c) 2014 KSDF 1229-0033/2014-3/32-38
제의 대체재로써 최근 활발히 연구되고 있다 ${ }^{1-3)}$.

피톤치드와 같은 천연 추출물들은 발향 주기가 수일 이내로 매우 짧아 오랜 기간 서방하기 위해서 캡슐에 담지하여 가공하는 방법이 주로 사용되고 있다. 일반적으로 의류의 기능성 가공에 사용되는 캡슐 가공에는 아크릴계 바인더나 우레탄계 바인더 가 사용되고 있으나 천연물질인 피톤치드 캡슐에 화학바인더보다는 천연재료에서 얻어진 바인더를 사용하려는 연구가 일부 시도되고 있다.

식물성 바인더로 사용되는 알긴산은 인체에 무독 성이며 물에 용해되어 고점성을 나타내므로 식품, 의약품 및 섬유 공업에서도 증점, 안정, 유화 등의 목적으로 사용되고 있다. 그러나 알긴산 원료는 그 자체로 사용하기에는 분자량이 너무 커 높은 점도 로 인한 공정 트러블이 발생할 가능성이 높기 때문 에 분자량을 조절해서 사용해야하므로 원하는 특성 을 얻기 위해 다른 구조의 폴리머를 혼합하여 혼성 중합체를 만드는 고분자 혼합방법에 대한 연구들이 이루어지고 있다-6. 
알긴산은 만루론산(M) 블록과 글루론산 $(\mathrm{G})$ 블록 및 그중간의 $\mathrm{M} / \mathrm{G}$ 블록이 1,4 -글리코시드로 결합된 공중합체로써 분자 속에 우론산의 카르복실기(-COOH) 가 있으므로 산의 성질을 나타내는데 보통은 나트륨 염(-COONa) 형태로 이용되고 있다. 알긴산은 $\mathrm{M} / \mathrm{G}$ 비 를 제어하는 것으로 겔 특성을 변화시키는 것이 가 능하며 $\mathrm{M} / \mathrm{G}$ 비율이 낮을수록 단단하고 부서지기 쉬 운 겔을 형성하고 높은 경우에는 보다 탄성적인 겔 로 변화한다. 또한 알긴산은 자중의 200 300배 이상 의 수분을 흡수하는 함습력을 가지고 있다고 알려져 있다 ${ }^{7-12)}$. 그러나 이런 특성에도 알긴산 자체는 물에 녹지 않기 때문에 가공에 어려움을 가지고 있어서 수용성 고분자이면서 무독성이고 생체친화성을 갖는 polyethylene oxide(PEO)와 혼합하여 접착제를 제조하 는 연구도 다수 진행되고 있다 ${ }^{13,14)}$.

따라서 본 논문에서는 피톤치드를 함유하는 캡슐 의 의류가공을 위해 천연 재료인 알긴산에 인체 친 화적인 수용성 고분자인 $\mathrm{PEO}$ 를 혼합하여 접착특성 의 변화를 관찰해보고자 한다.

\section{2. 실 험}

\section{1 시료 및 시약}

바인더로 사용된 Alg-Na(alginic acid sodium salt, mw:250,000, CAS 9005-38-3)와 PEO(polyethylene oxide, mw:400,000, CAS 25322-68-3)는 sigma aldrich에서 구 매하여 사용하였고 접착강도 시험에 사용된 원단은 테스트패브릭사의 AATCC CROCK CLOTH 표준면 포를 사용하였다.

\section{2 실험방법}

\subsection{1 점도측정}

$\mathrm{Alg}-\mathrm{Na}$ 와 $\mathrm{PEO}$ 를 혼합하였을 때의 점도변화를 관 찰하기 위해 Alg-Na 1, 3, 5\%와 PEO 0, 1, 3, 5\%를 혼 합하여 혼합용액을 제조하였으며 브룩필드사의 디지 털비스코미터 DV-II pro를 이용하여 $20^{\circ} \mathrm{C}$ 항온상태 에서 점도를 측정하였다.

\subsubsection{FT-IR 분석}

$\mathrm{Alg}-\mathrm{Na}$ 와 $\mathrm{PEO}$ 가 혼합되었을 때 점도가 증가하는 원인을 분석하기 위해 Alg-Na 3\%용액과 PEO 3\%용 액을 제조한 후 두 용액의 비를 $100: 0,80: 20,60: 40$, $40: 60,20: 80,0: 100 \%$ 로 변화시켜 혼합용액을 제조하였 으며, Thermo Nicolet사의 FT-IR 적외선분광기 AVATAR
370 을 이용하여 $650 \sim 4000 \mathrm{~cm}^{-1}$ 범위에서 ATR 법으로 분석하였다.

\subsection{3 열분석}

$\mathrm{Alg}-\mathrm{Na} / \mathrm{PEO}$ 혼합용액의 열에 대한 특성을 분석하 기 위해 워터스사의 열중량분석기(TGA) Q 500을 이 용하여 $100 \mathrm{ml} / \mathrm{min}$ 질소 분위기에서 $10^{\circ} \mathrm{C} / \mathrm{min}$ 속도로 $30^{\circ} \mathrm{C}$ 에서 $600^{\circ} \mathrm{C}$ 까지 분해거동을 측정하였으며, 시차 주사열량계(DSC) Q 100 을 이용하여 $50 \mathrm{ml} / \mathrm{min}$ 질소 분위기에서 $10^{\circ} \mathrm{C} / \mathrm{min}$ 속도로 $20^{\circ} \mathrm{C}$ 에서 $170^{\circ} \mathrm{C}$ 까지 열 량의 변화를 분석하였다.

\subsection{4 접촉각 측정}

Alg-Na와 PEO 혼합액이 면 원단에 처리되었을 때 표면에서의 변화를 분석하기 위해 GBX사의 digidrop 을 이용하여 drop size $6 \mu l$ 로 표면접촉각을 측정하였다.

\subsection{5 접착강도 측정}

접착강도는 테스트패브릭사의 AATCC $\mathrm{CROCK}$ CLOTH 표준면포를 이용하여 Alg-Na와 PEO 3\% 혼 합용액을 가로 $5 \mathrm{~cm}$, 세로 $10 \mathrm{~cm}$ 인 2 개의 원단에 골고 루 펴 바른 후 접착시키고 $160^{\circ} \mathrm{C}$ 오븐에서 5 분간 건 조한 후 한쪽 끝을 박리한 다음 인스트론사의 만능재 료 시험기를 이용하여 시험편이 박리될 때 최대 하중 을 측정하였다.

\subsection{6 표면분석}

피톤치드를 함유하는 마이크로 캡슐을 부착한 원 단은 히타치사의 S-3000N 주사전자현미경을 이용하여 캡슐가공한 원단의 세탁 전후의 표면을 측정하였다. 캡슐 가공은 마이크로캡슐 o.w.f $3 \%$, 바인더 3\%, 텐터 온도 $160^{\circ} \mathrm{C}$ 에서 120 초간 처리하였으며 가공포의 세탁 은 가정용 세탁기의 표준조건으로 20 회 세탁하여 건조 후 원단 표면에 부착되어 있는 캡슐을 관찰하였다.

\section{3. 결과 및 고찰}

\subsection{PEO 함량에 따른 점도변화}

Figure 1은 Alg-Na 1, 3, 5\%에 PEO를 각각 $0,1,3$, $5 \%$ 씩 혼합하면서 점도의 변화를 측정한 것이다. $\mathrm{PEO}$ 의 함량이 증가함에 따라 점도도 점차 증가하였 으며 특히, $\mathrm{Alg}-\mathrm{Na}$ 의 함량 $5 \%$ 에서는 $\mathrm{PEO}$ 함량이 증 가함에 따라서 점도가 급격하게 증가하는 것을 확인 할 수 있었다. 너무 큰 점도는 실제공정에 문제를 야 기할 수 있으므로 바인더 제조 시에는 Alg-Na가 3\% 이내가 되도록 할 필요가 있다. 


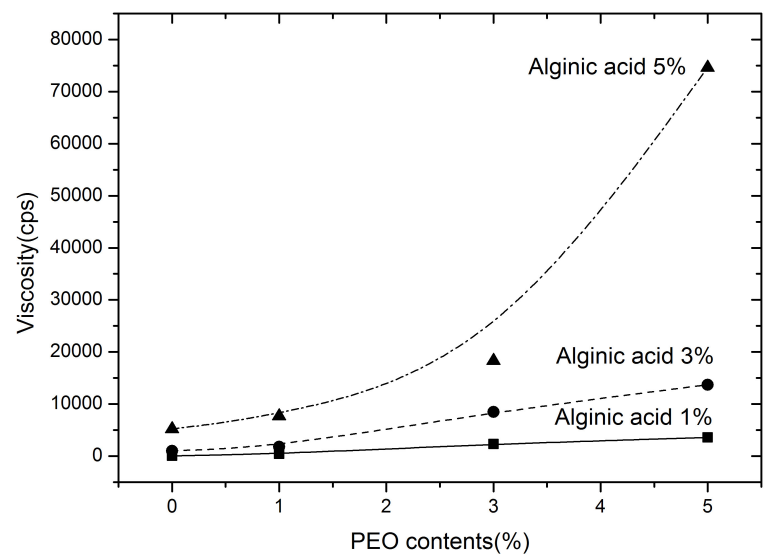

Figure 1. Change of the viscosity of the Alg-Na/PEO blend solutions.

\subsection{Alg-Na/PEO 혼합용액의 FT-IR 분석}

$\mathrm{Alg}-\mathrm{Na}$ 함량이 5\%일 때 $\mathrm{PEO}$ 함량이 증가함에 따 라 점도가 급격하게 증가하여 $\mathrm{Alg}-\mathrm{Na}$ 와 $\mathrm{PEO}$ 를 각각 $3 \%$ 용액으로 제조하였고 이 용액으로부터 Alg-Na:PEO 의 함량비를 $100: 0,80: 20,60: 40,40: 60,20: 80,0: 100 \%$ 로 혼합한 후 $\mathrm{Alg}-\mathrm{Na} / \mathrm{PEO}$ 혼합용액의 결합구조를 확 인하기 위해 적외선분광분석기(FT-IR)로 분석하였다.

Figure 2에는 혼합용액의 FT-IR 스펙트럼을 나타내 었다. $843 \mathrm{~cm}^{-1}$ 에서 나타나는 피크는 -C-O-C- 굽힘에 의한 피크이며, Alg-Na의 hydroxyl group에 의한 피크 가 $3500 \mathrm{~cm}^{-1}$ 근처에서 관찰되었다.

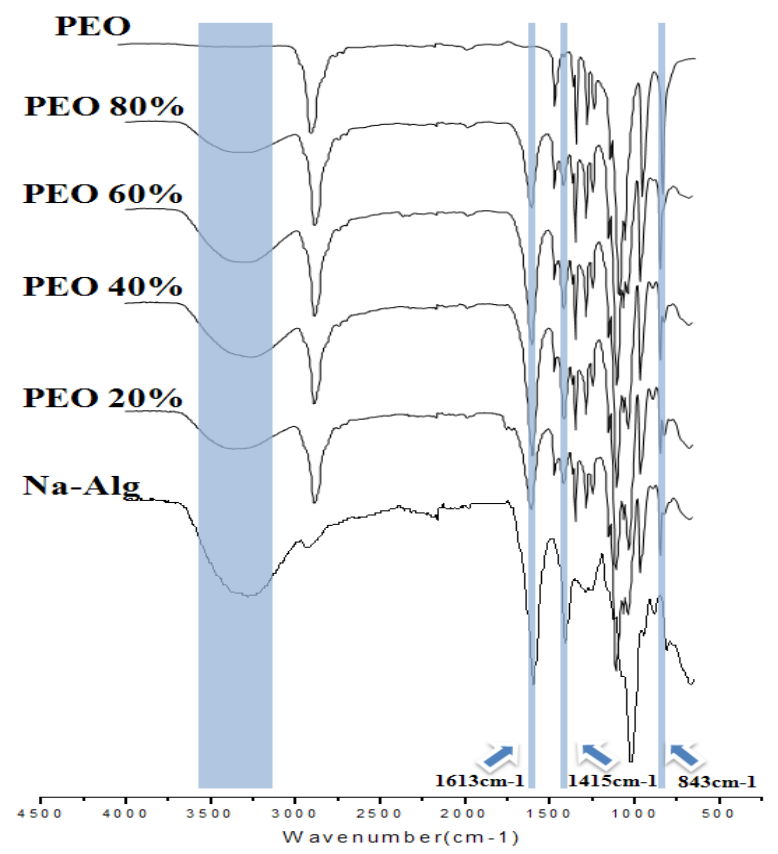

Figure 2. FT-IR spectrums of the Alg-Na/PEO blend solutions.

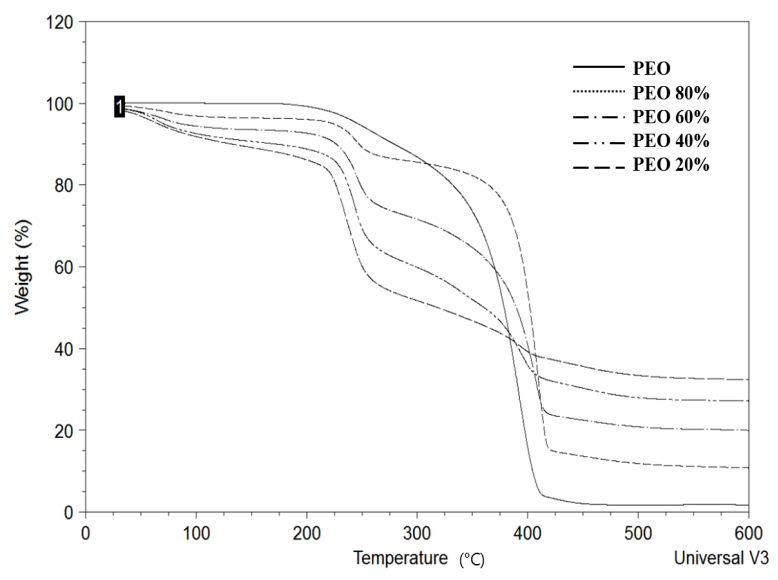

Figure 3. TGA curves of the Alg-Na/PEO blend solutions.

또한 -COO 스트레칭에 의한 피크도 $1613 \mathrm{~cm}^{-1}$ 와 $1415 \mathrm{~cm}^{-1}$ 에서 관찰되었다. $\mathrm{Alg}-\mathrm{Na}$ 와 $\mathrm{PEO}$ 의 수소결합 에 의한 피크는 $3500 \mathrm{~cm}^{-1}$ 근처에서 완만하게 나타났 으며 $\mathrm{PEO}$ 함량이 증가함에 따라 피크가 커지다가 $\mathrm{PEO}$ 함량이 $60 \%$ 이상에서 오히려 줄어드는 경향을 나타내었는데 $\mathrm{PEO}$ 함량이 $60 \%$ 이상으로 증가하면 $\mathrm{PEO}$ 와 수소결합 할 수 있는 $\mathrm{Alg}-\mathrm{Na}$ 의 $-\mathrm{OH}$ 기가 상대 적으로 줄어들기 때문인 것으로 생각된다.

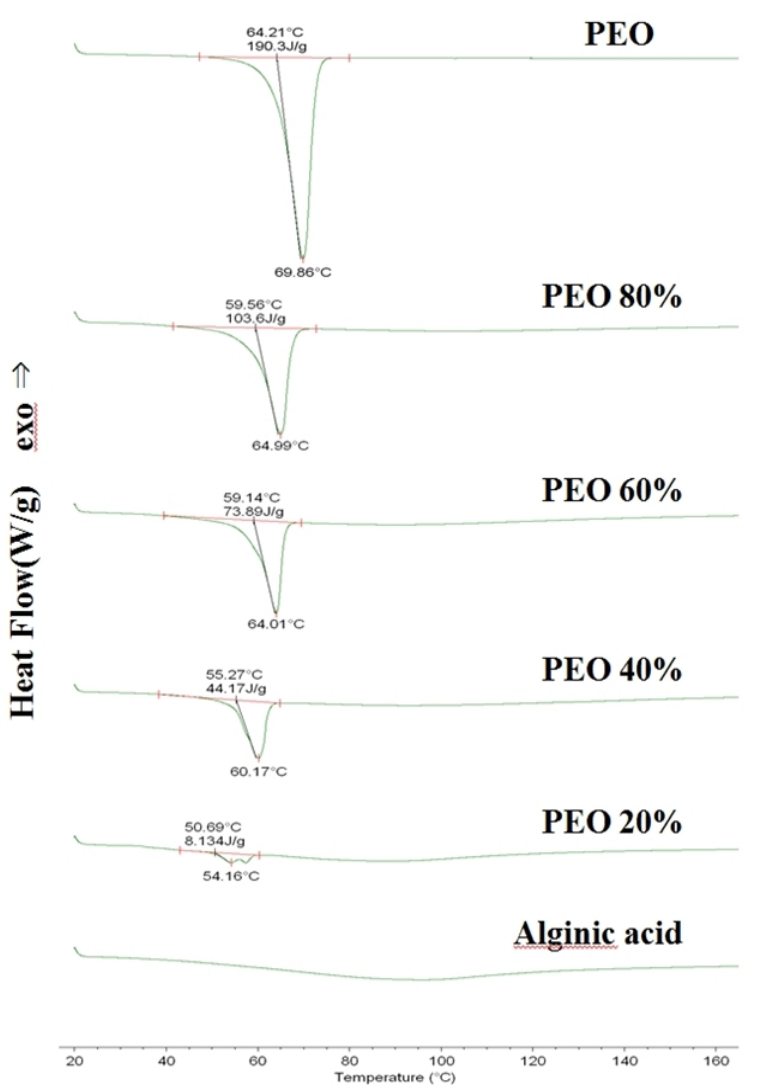

Figure 4. DSC curves of the Alg-Na/PEO blend solutions. 


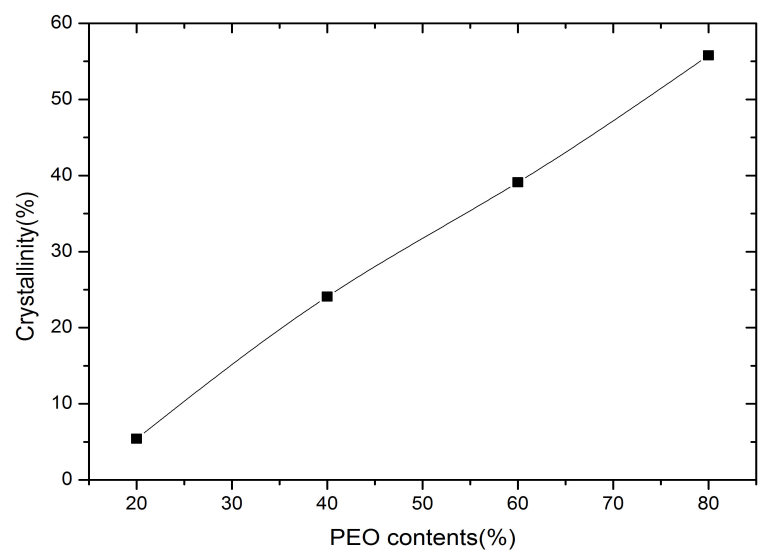

Figure 5. Change of the crystallinity of the Alg-Na/PEO blend solutions.

\subsection{Alg-Na/PEO 혼합용액의 TGA 분석}

Figure 3은 Alg-Na/PEO 혼합용액의 TGA 분석결과 를 나타낸 그래프이다. $\mathrm{PEO}$ 함량이 증가함에 따라서 초기 열분해 온도가 증가하는 경향을 나타내었으나 $\mathrm{PEO}$ 함량이 $60 \%$ 이상에서는 큰 변화를 보이지 않았다.

\subsection{Alg-Na/PEO 혼합용액의 DSC 분석}

Figure 4는 Alg-Na/PEO 비율별 혼합용액의 DSC 분 석 결과를 나타낸 그래프로써 PEO $100 \%$ 일 때는 녹는 온도가 약 $70^{\circ} \mathrm{C}$ 였으나 $\mathrm{PEO}$ 비율이 작아지면서 녹는 온도는 $60^{\circ} \mathrm{C}$ 로 점차 감소하였다.

Figure 5는 DSC 결과로부터 얻어진 $\mathrm{PEO}$ 의 함량에 따른 결정화도의 변화를 나타낸 그래프이다. $\mathrm{PEO}$ 함량이 감소함에 따라서 결정화도 또한 감소하는 경 향을 보이는데 이는 $\mathrm{Alg}-\mathrm{Na}$ 의 강한 분자쇄로 인해 $\mathrm{Alg}-\mathrm{Na} / \mathrm{PEO}$ 혼합용액에서 분자쇄의 이동성이 저하되 어 나타나는 것으로 생각된다.

\section{$3.5 \mathrm{Alg}-\mathrm{Na} / \mathrm{PEO}$ 혼합용액을 처리한 원단의 표 면접촉각 분석}

Figure 6은 Alg-Na/PEO 혼합용액으로 처리한 면 원 단의 표면 접촉각을 측정한 그래프이다. $\mathrm{PEO}$ 함량이

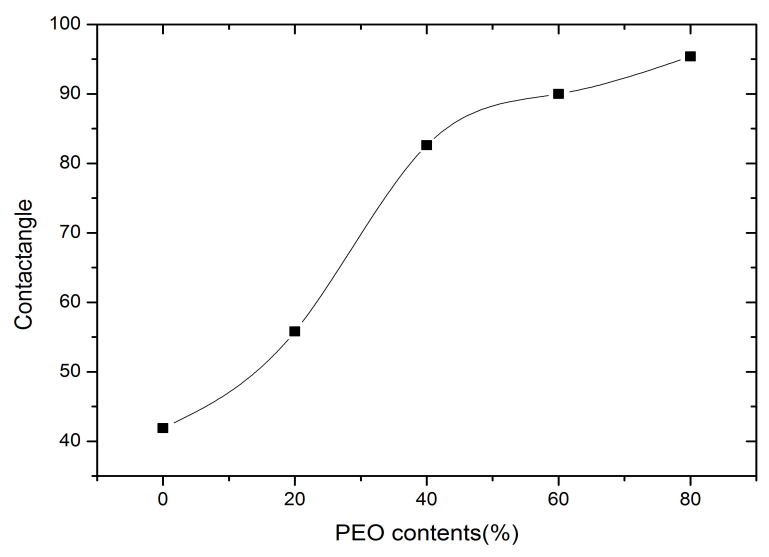

Figure 6. Surface contact angles of the cotton fabric treated with the Alg-Na/PEO blend solutions.

증가함에 따라서 면 원단의 접촉각은 점차 증가하였으 며 $\mathrm{PEO}$ 함량이 $40 \%$ 로 증가할 때까지 접촉각이 급격히 증가하다가 $40 \%$ 이상에서 부터는 접촉각이 완만하게 변화하는 경향을 보이고 있다. $\mathrm{Alg}-\mathrm{Na}$ 는 수용성 고분자 로 친수성이나 $\mathrm{PEO}$ 와 혼합되면 분자간 수소결합을 형성하여 표면특성이 소수성으로 바뀌어 접촉각이 증 가하나 $40 \%$ 이상에서는 수소결합을 형성할 수 있는 $\mathrm{Alg}-\mathrm{Na}$ 의 반응기가 없어 접촉각은 완만해 지는 것으로 생각된다.

Figure 7에 혼합용액으로 처리된 표준면포에서 $\mathrm{PEO}$ 함량에 따라 맺히는 물방울의 사진을 보였다.

\subsection{Alg-Na/PEO 혼합용액의 물성 변화}

Figure 8은 Alg-Na/PEO 혼합용액으로 처리한 면 원단의 박리강도를 나타낸 그래프이다. $\mathrm{Alg}-\mathrm{Na} / \mathrm{PEO}$ 혼합용액에서 $\mathrm{PEO}$ 함량이 증가할수록 박리강도는 증가하나 PEO 함량이 $50 \%$ 이상에서는 오히려 박리 강도가 저하되는 것을 보이고 있는데 이는 $\mathrm{PEO}$ 함량 이 $50 \%$ 이상으로 높아지면 $\mathrm{Alg}-\mathrm{Na}$ 와 $\mathrm{PEO}$ 의 수소결 합에는 큰 변화가 없으나 cellulose와의 접착은 $\mathrm{PEO}$ 의 함량이 증가함에 따라 PEO 물성에 영향을 받기 때문 에 박리강도는 오히려 저하되는 것으로 판단된다.

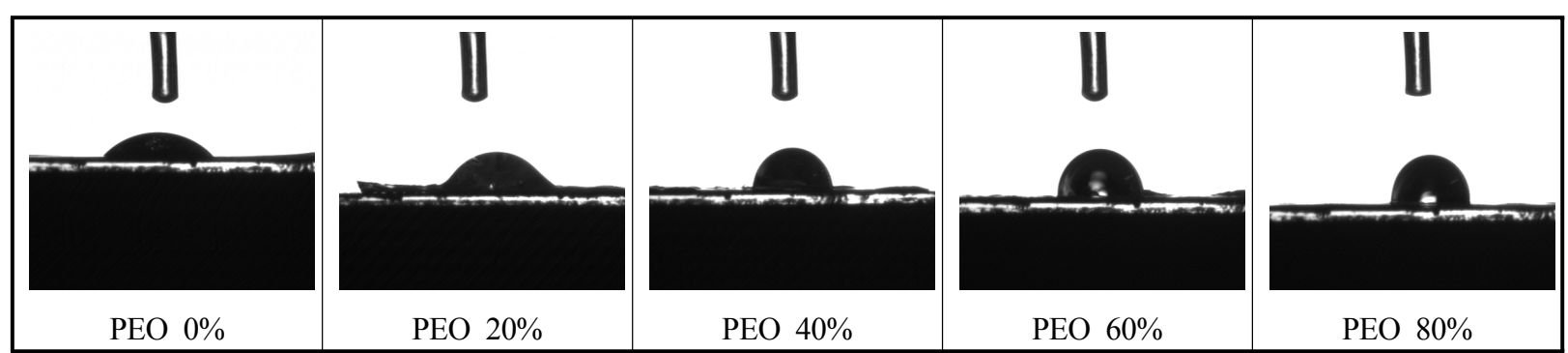

Figure 7. The photographs of surface contact of water on the cotton fabric treated with the Alg-Na/PEO blend solutions. 


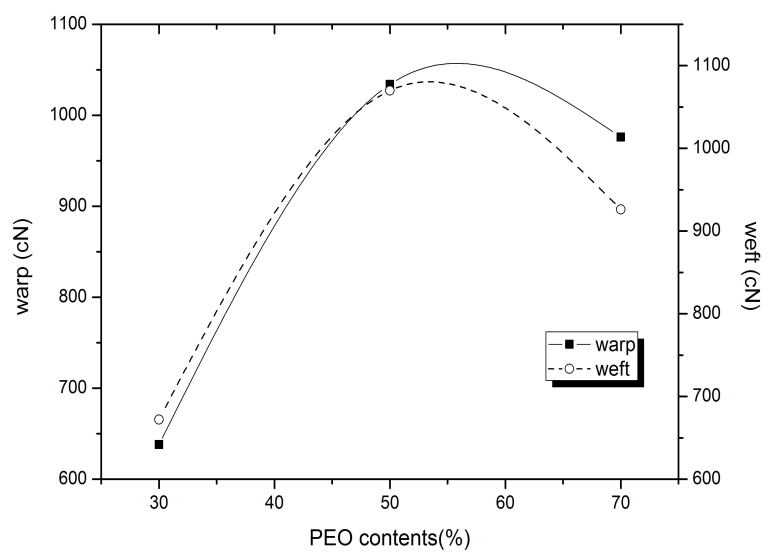

Figure 8. Change of the peel strength of the Alg-Na/PEO blend solutions.

\section{7 세탁 전후 캡슐가공한 면포의 표면분석}

Figure 9는 Alg-Na:PEO 함량비가 각각 100:0((a), (b), (c)) 및 50:50((d), (e), (f))인 용액으로 캡슐 가공하 여 얻어진 세탁 전 및 세탁 후의 사진으로써 세탁 전 에는 두 함량비 모두 캡슐이 유사하게 부착되어 있 다. 그러나 세탁 10 회, 20 회 후에는 PEO 함량이 $0 \%$ 인 $\mathrm{Alg}-\mathrm{Na} 100 \%$ 로 처리된 원단((c), (d))에는 잔류하고 있는 캡슐을 발견할 수 없었으나 PEO 50\%인 (e), (f) 의 경우에는 세탁 후에도 잔류하고 있는 캡슐을 일부 확인할 수 있었다.

Figure 10은 Staphylococcus aureus(황색포도상구균) 으로 (d), (e), (f) 원단의 정균감소율 시험결과를 나타

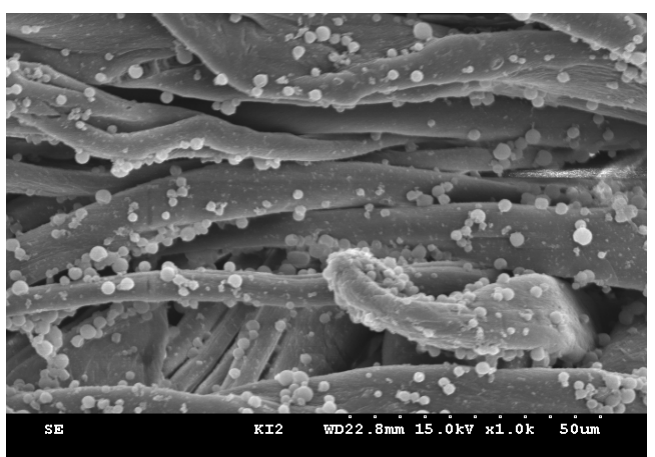

(d) before laundry(PEO 50\%)

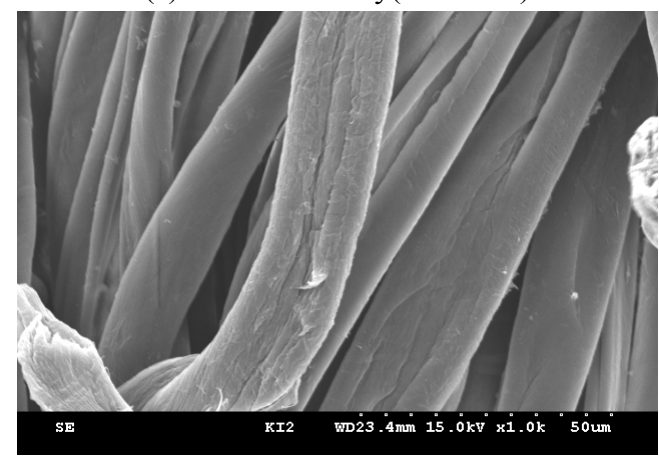

(b) after laundry 10 times(PEO 0\%)

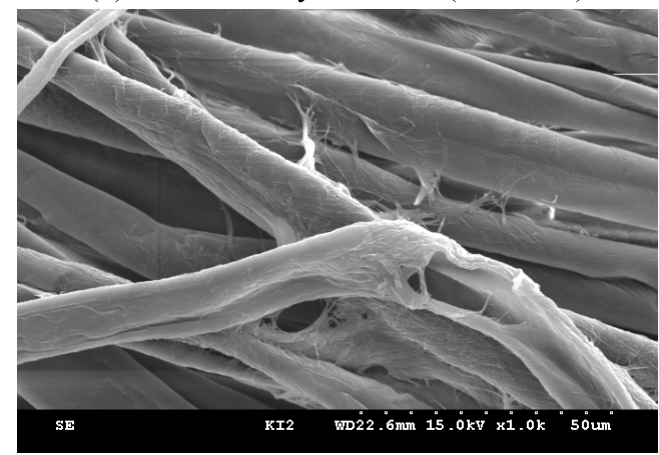

(c) after laundry 20 times(PEO 0\%)

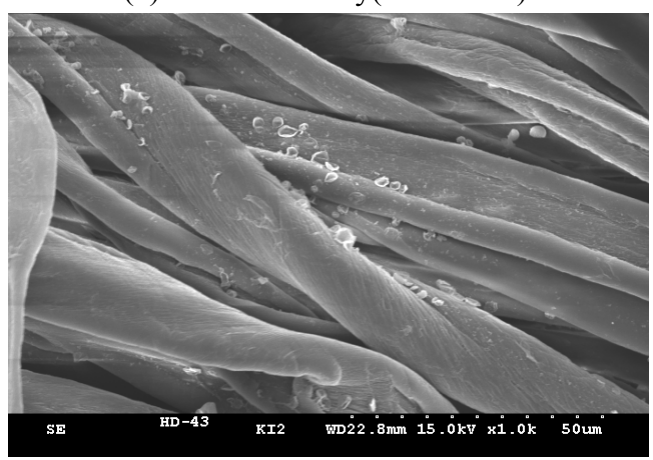

(e) after 10 times laundry(PEO 50\%)

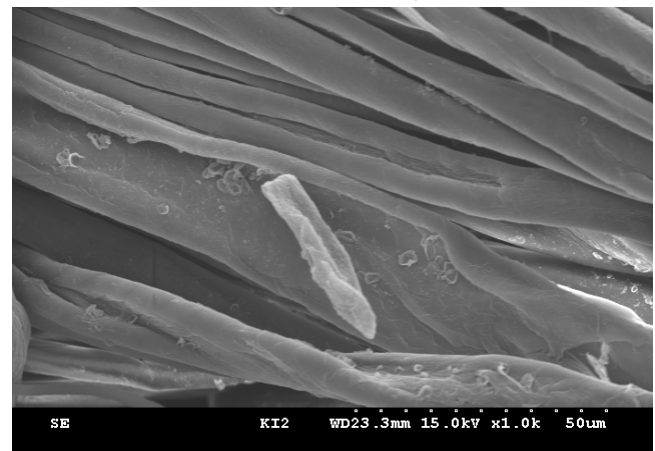

(f) after laundry 20 times(PEO 50\%)

Figure 9. The photographs of before and after laundry of capsule finished fabric with alginic binder consisted of zero or half PEO content. 


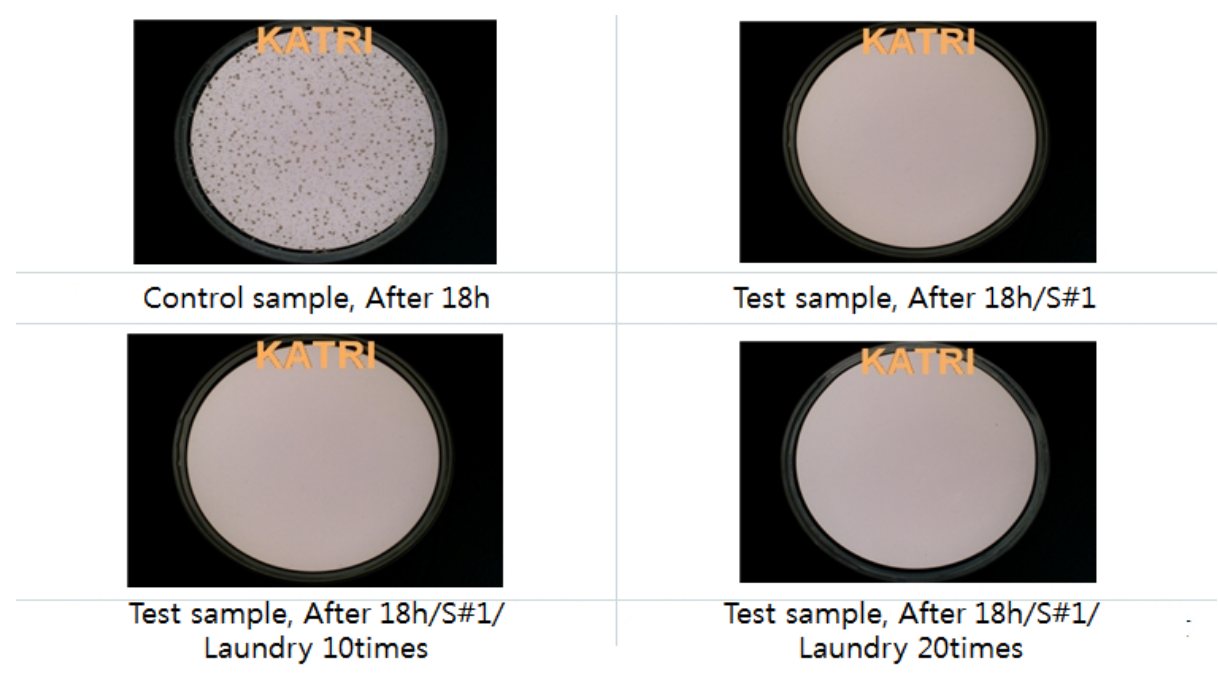

Figure 10. Images of antibacterial test of capsule finished fabric with alginic binder consisted of zero or half PEO content.

낸 그림으로 세탁 후에도 피톤치드 마이크로캡슐이 섬유내부에 잔류하고 있어 $99.9 \%$ 의 항균성을 나타내 는 것으로 생각된다.

\section{4. 결 론}

본 연구에서는 피톤치드와 같은 천연 기능성 물질 들을 서방하기 위한 캡슐 가공을 위해 인체에 친화적 인 알긴산 바인더의 접착성질을 개선하고자 하였으 며 천연 재료인 알긴산에 인체 친화적인 수용성 고분 자인 $\mathrm{PEO}$ 를 비율별로 혼합하여 열분석, 물성분석 등 을 통해 접착특성의 변화를 관찰하여 다음과 같은 결 론을 얻었다.

1. Alg-Na와 PEO의 함량이 증가할수록 혼합용액의 점도가 증가하였고, 특히 $\mathrm{Alg}-\mathrm{Na}$ 의 함량 $5 \%$ 에서는 $\mathrm{PEO}$ 함량이 증가함에 따라 점도가 급격하게 증가 하는 것을 확인할 수 있었다.

2. FT-IR 분석 결과, Alg-Na와 $\mathrm{PEO}$ 의 수소결합에 의 한 피크는 $3500 \mathrm{~cm}^{-1}$ 근처에서 완만하게 나타났고 $\mathrm{PEO}$ 함량이 증가함에 따라 피크가 커지다가 $\mathrm{PEO}$ 함량이 $60 \%$ 이상에서 오히려 줄어드는 경향을 나 타내었다.

3. TGA 분석결과에서는 $\mathrm{PEO}$ 함량이 증가함에 따라 초 기 열분해 온도가 증가하는 경향을 보이다가 $\mathrm{PEO}$ 함량이 $60 \%$ 이상에서는 큰 변화를 보이지 않았다.

4. $\mathrm{PEO} 100 \%$ 일 때는 녹는 온도가 약 $70^{\circ} \mathrm{C}$ 였으나 $\mathrm{PEO}$ 비율이 작아지면서 녹는 온도는 $60^{\circ} \mathrm{C}$ 로 점차 감소 하였고 결정화도 또한 감소하는 경향을 보였다.
5. $\mathrm{PEO}$ 함량이 증가함에 따라서 면 원단의 접촉각은 점차 증가하였으나 $40 \%$ 이상에서 부터는 접촉각 이 완만하게 변화하는 경향을 보였다. $\mathrm{PEO}$ 함량이 $50 \%$ 까지는 박리강도가 증가하였으나 그 이상에서 는 감소하는 경향을 보였다.

\section{감사의 글}

본 연구는 광역경제권연계협력개발(과제번호 $\mathrm{R}$ 0000653 ) 사업의 지원으로 수행된 연구결과입니다.

\section{References}

1. Y. W. Kim, S. J. Lee, and E. H. Kim, The Function of the Natural Extract and the Situation of the Clinical Study, Fiber Technology and Industry, 17(3), 180(2013).

2. H. G. Kim, N. S. Yoon, M. W. Huh, and I. S. Kim, Physicochemical Properties of Non-Formaldehyde Resin Finished Cotton Fabric and their Optimal Treatment Condition, Textile Coloration and Finishing(J. of Korea Soc. Dyers and Finishers), 24(2), 121(2012).

3. H. G. Kim, N. S. Yoon, M. W. Huh, and S. K. Jeon, Physicochemical Properties of Non-Formaldehyde Resin Finished Rayon Fabric and Their Optimal Treatment Condition, Textile Coloration and Finishing(J. of Korea Soc. Dyers and Finishers), 24(3), 221(2012). 
4. J. J. Yoo and I. W. Lee, "Preparation and Characterization of Sodium Alginate/PEO and Sodium Alginate/PVA Nanofiber, Tissue Engineering : Concepts and Application", Korea Medical Book Publisher, Seoul, pp.21-36, 1998.

5. E. 1. Hirst, J. K. N. Jones, and W. O. Jones, The Structure of Alginic Acid-Part I, J. of the Chemical Society, 0, 1880(1939).

6. S. M. Han, C. W. Nam, and S. W. Kim, Preparation of Sodium Alginate/poly(ethylene oxide) Blend Nanofibers with Lecithin, J. of the Korean Fiber Society, 37, 365(2000).

7. Y. Qin, The Characterization of Alginate Wound Dressings with Different Fiber and Textile Structures, J. of Applied Polymer Science, 91, 1641(2004).

8. Q. Yimin, H. Hu, and A. Luo, The Conversion of Calcium Alginate Fibers into Alginic Acid Fibers and Sodium Alginate Fibers, J. of Applied Polymer Science, 101(6), 4216(2006).

9. M. Kitamikado, K. Yanaguchi, C. H. Tseng, and B. Okabe, Method Designed To Detect Alginate -Degrading Bacteria, Appl. Envir. Microbio., 56, 2939(1990).
10. R. S. Doubet and S. Q. Ralph, Properties of Alginate Lyases from Marine Bacteria, Appl. Envir. Microbio., 47(4), 699(1984).

11. Y. Liu, J. Chen, N. T. Anh, C. O. Too, V. Misoska, and G. G. Wallace, Nanofiber Mats from DNA, SWNTs, and Poly(ethylene oxide) and their Application in Glucose Biosensors, Electrochemical Society J., 155(5), K100(2008).

12. S. Hirano, Formatoin of the Polyelectrolyte Complexes of Some Acidic Glycosaminoglycans with Partially N-acylated Chitosans, Biopolymers, 17(3), 805(1978).

13. Y. J. Lee, D. S. Shin, O. W. Kwon, W. H. Park, H. G. Choi, Y. R. Lee, S. S. Han, S. K. Noh, and W. S. Lyoo, Preparation of Atactic Poly(vinyl alcohol) /Sodium Alginate Blend Nanowebs by Electrospinning, J. of Applied Polymer Science, 106(2), 1337 (2007).

14. P. R. Hari, T. Chandy, and C. P. Sharma, Chitosan /calcium Alginate Microcapsules for Intestinal Delivery of Nitrofurantoin, J. of Applied Polymer Science, 59, 1795(1996). 